\title{
Perceived Stigma as a Risk Factor for Delay in Seeking Treatment of Leprosy Patients: A Cross- Sectional Study in Tuban Regency
}

\author{
Zulfah Fitria Fajriahadun Ni'mah, Nissa Kusariana, Praba Ginandjar* \\ Department of Epidemiology and Tropical Disease, Faculty of Public Health, Diponegoro University
}

\begin{abstract}
Tuban Regency is a leprosy endemic area. Leprosy prevalence in 2018 was 1.5 per 10,000 population with 177 new cases, about $87 \%$ of new leprosy cases are MB type and $11 \%$ have grade II disability. The high number of MB type and grade II disability leads to the low awareness of treatment-seeking behavior, as early as immediately after symptoms appear. This study aimed to prove that perceived stigma is a risk factor for delay in seeking treatment for leprosy patients. Cross-sectional study design was used in this study and the subject consisted of 112 leprosy patients, selected by proportional random sampling. Data were collected using a structured questionnaire. This study showed most of the subjects ranged from 15-60 years, more than half were male, most had low levels of education with low income. Most subjects suffered from the MB type of leprosy. More than half experienced delays in seeking treatment and did not experience disabilities. The variables such as knowledge, attitude, perceived susceptibility and severity of leprosy, and perceived stigma associated with the delay in seeking treatment, and only perceived stigma was proven as a risk factor for delay in seeking treatment of leprosy patients $(\mathrm{p}=0.002$; OR $4.458(95 \%$ CI; 1,700-11,690)
\end{abstract}

\section{Background}

Leprosy is a chronic infectious disease that attacks the peripheral nerves, caused by the rodshaped bacteria Mycobacterium leprae [1,2]. The prevalence of leprosy in Indonesia was 0.70 cases per 10,000 population in 2017 , and East Java became the region with the highest number of new leprosy cases, recorded 3,373 cases, and had a prevalence rate of 0.93 per 10,000 population [3, 4]. Leprosy can be cured with appropriate treatment, using Multi-Drug Therapy (MDT). MDT can also prevent disability, although disability that occurs before treatment cannot be cured with MDT. The treatment of leprosy must be done as early as possible since the first symptoms discovered [5].

Tuban Regency is one of the leprosy endemic areas in East Java Province, as many as 175 leprosy patients registered and still undergoing treatment until 2018. The prevalence of leprosy in the Tuban Regency was 1.50 per 10,000 population, while the national leprosy prevalence target was 1 per 10,000 population. Also, in 2018 there were also 177 new cases

* Corresponding author: praba.ginandjar@live.undip.ac.id 
in Tuban Regency of leprosy which consist of $87 \%$ of MB leprosy sufferers, $18 \%$ grade I disability, and $11 \%$ grade II disability [6]. The indicator of leprosy control in Indonesia is the proportion of grade II disability not more than 5\%. The high proportion of MB type of leprosy and the presence of disability leads to low awareness of patients in seeking early treatment.

\section{Methods}

The study was an analytic observational study with a cross-sectional study approach. The population of this study was leprosy patients who registered in the leprosy cohort registry data of the Tuban Regency Health Office and still undergoing leprosy treatment until 2018. Obtained 112 respondents as a sample of this study. The research subjects were selected by a proportional random sampling technique based on the number of leprosy patients in each Public Health Center (PHC). There are 28 PHCs in Tuban Regency. The number of subjects in each PHC selected ranged from 1-9 leprosy patients.

The variables of this study consisted of characteristics including age, gender, education level, type of work, income level, type of leprosy, grade/level of disability, knowledge, attitude, perceived vulnerability, and seriousness of leprosy, perceived stigma, and delay in seeking leprosy treatment.

The age variable categorized into two categories, non-productive age (age $<15$ years old and $\geq 65$ years old) and non-productive age (15-64 years). The education level variable is categorized as low education, (did not take 12 years of compulsory education) and higher education (took 12 years of compulsory education). The income level variable categorized as low income (income $<2,333,641$ IDR) and the high income (income $\geq 2,333,641$ IDR).

\section{Results}

\subsection{Characteristics of subjects}

The results of this study indicate that the majority of respondents who experienced a delay in seeking treatment occurred in respondents with a non-productive age group $(87.5 \%)$ compared to the productive age group $(59.4 \%)$, in addition to the proportion of respondents who experienced a delay in seeking treatment a lot occurred in female $(69.4 \%)$ compared to male $(58.7 \%)$. delay in seeking leprosy treatment are also more experienced by respondents who have low education (63.9\%) compared to respondents with higher education (50\%), and most respondents who experience delays in seeking treatment are experienced by respondents with low incomes $(66.7 \%)$ compared respondents with high income $(50.0 \%)$. Age group was a factor related to delay in seeking leprosy treatment $(\mathrm{p}=0.031)$. Gender, education level, and income level $(\mathrm{p}=0.245 ; 0.571 ; 0.146)$ were not factors related to the delay in seeking leprosy treatment. (Table 1). 
Table 1. Characteristics of subjects.

\begin{tabular}{|c|c|c|c|c|c|c|c|c|}
\hline \multirow[t]{2}{*}{ No } & \multirow{2}{*}{$\begin{array}{c}\text { Characterist } \\
\text { ics }\end{array}$} & \multicolumn{2}{|c|}{$\begin{array}{c}\text { Delay in } \\
\text { seeking }\end{array}$} & \multicolumn{2}{|c|}{$\begin{array}{c}\text { Not delay in } \\
\text { seeking }\end{array}$} & \multirow[t]{2}{*}{$\begin{array}{c}\mathrm{p}- \\
\text { value }\end{array}$} & \multirow[t]{2}{*}{ OR } & \multirow[t]{2}{*}{$95 \% \mathrm{CI}$} \\
\hline & & $\mathrm{n}$ & $\%$ & $\mathrm{n}$ & $\%$ & & & \\
\hline \multirow[t]{3}{*}{1} & \multicolumn{8}{|l|}{ Age } \\
\hline & $\begin{array}{l}\text { Non- } \\
\text { Productive }\end{array}$ & 14 & 87,5 & 2 & 12,5 & \multirow{2}{*}{0,031} & \multirow{2}{*}{4,789} & \multirow{2}{*}{$1,030-22,264$} \\
\hline & Productive & 57 & 59,4 & 39 & 40,6 & & & \\
\hline \multirow[t]{3}{*}{2} & \multicolumn{8}{|l|}{ Gender } \\
\hline & Male & 37 & 58,7 & 26 & 41,3 & \multirow{2}{*}{0,245} & \multirow{2}{*}{0,628} & \multirow{2}{*}{$0,286-1,380$} \\
\hline & Female & 34 & 69,4 & 15 & 30,6 & & & \\
\hline \multirow[t]{3}{*}{3} & \multicolumn{8}{|c|}{ Education level } \\
\hline & Low & 69 & 63,9 & 39 & 36,1 & \multirow{2}{*}{0,571} & \multirow{2}{*}{1,769} & \multirow{2}{*}{$0,240-13,059$} \\
\hline & High & 2 & 50,0 & 2 & 50,0 & & & \\
\hline \multirow[t]{3}{*}{4} & \multicolumn{8}{|l|}{ Income level } \\
\hline & Low & 60 & 66,7 & 30 & 32,9 & \multirow{2}{*}{0,146} & \multirow{2}{*}{2,000} & \multirow{2}{*}{$0,778-5,139$} \\
\hline & High & 11 & 50,0 & 11 & 50,0 & & & \\
\hline
\end{tabular}

\subsection{Factors related to delay in seeking treatment}

Table 2 shows that family support and access to health services $(\mathrm{p}=0.293 ; 0.844)$ were not related to the delay in seeking treatment. But on the contrary, the level of knowledge, attitudes toward perceived symptoms, perceived vulnerability and seriousness of perceived symptoms, and perceived stigma ( $\mathrm{p}=0.004 ; 0.030 ; 0.003 ; 0.021)$ are factors related to the delay in seeking treatment. However, after multivariate analysis, table 3 shows that only perceived stigma is a risk factor for delay in seeking treatment $(\mathrm{p}=0.002$; Adjusted $\mathrm{OR}=4,458 ; 95 \%$ CI $(1,700-11,690)$.

Table 2. Factors related to delay in seeking treatment.

\begin{tabular}{|c|c|c|c|c|c|c|c|c|}
\hline \multirow[b]{2}{*}{ No } & \multirow{2}{*}{ Variables } & \multicolumn{2}{|c|}{$\begin{array}{c}\text { Delay in } \\
\text { seeking }\end{array}$} & \multicolumn{2}{|c|}{$\begin{array}{l}\text { Not delay in } \\
\text { seeking }\end{array}$} & \multirow[t]{2}{*}{ p-value } & \multirow[t]{2}{*}{ OR } & \multirow[t]{2}{*}{$95 \% \mathrm{CI}$} \\
\hline & & $\mathrm{n}$ & $\%$ & $\mathrm{n}$ & $\%$ & & & \\
\hline \multirow[t]{3}{*}{1} & \multicolumn{8}{|c|}{ Level of knowledge } \\
\hline & Poor & 35 & 79,5 & 9 & 20,5 & \multirow{2}{*}{0,004} & \multirow{2}{*}{3,457} & \multirow{2}{*}{$1,443-8,282$} \\
\hline & Good & 36 & 52,9 & 32 & 47,1 & & & \\
\hline \multirow[t]{3}{*}{2} & \multicolumn{8}{|c|}{ Attitudes toward perceived symptoms } \\
\hline & Poor & 28 & 77,8 & 8 & 22,2 & \multirow{2}{*}{0,030} & \multirow{2}{*}{2,686} & \multirow{2}{*}{$1,084-6,655$} \\
\hline & Good & 43 & 56,6 & 33 & 43,4 & & & \\
\hline \multirow[t]{3}{*}{3} & \multicolumn{8}{|c|}{ Perceived vulnerability and seriousness of perceived symptoms } \\
\hline & Poor & 43 & 76,8 & 13 & 23,2 & \multirow{2}{*}{0,003} & \multirow{2}{*}{3,308} & \multirow{2}{*}{$1,469-7,450$} \\
\hline & Good & 28 & 50,0 & 28 & 50,0 & & & \\
\hline
\end{tabular}




\begin{tabular}{|c|c|c|c|c|c|c|c|c|}
\hline \multirow[t]{3}{*}{4} & \multicolumn{8}{|c|}{ Family support } \\
\hline & Poor & 35 & 68,6 & 16 & 31,4 & \multirow{2}{*}{0,293} & \multirow{2}{*}{1,519} & \multirow{2}{*}{$0,696-3,318$} \\
\hline & Good & 36 & 59,0 & 25 & 41,0 & & & \\
\hline & \multicolumn{8}{|c|}{ Perceived Stigma } \\
\hline & Present & 47 & 72,3 & 18 & 27,7 & \multirow{2}{*}{0,021} & \multirow{2}{*}{2,502} & \multirow{2}{*}{$1,137-5,507$} \\
\hline & Not present & 24 & 51,1 & 23 & 48,9 & & & \\
\hline \multirow[t]{3}{*}{6} & \multicolumn{8}{|c|}{ Access to health services } \\
\hline & Unreachable & 36 & 64,3 & 20 & 35,7 & \multirow{2}{*}{0,844} & \multirow{2}{*}{1,080} & \multirow{2}{*}{$0,501-2,330$} \\
\hline & Reachable & 35 & 62,5 & 21 & 37,5 & & & \\
\hline
\end{tabular}

\section{Discussion}

Leprosy patients often get a negative stigma from the social community about the disease and disability suffered. This stigma can lead to the emergence of perceived stigma where patients will feel fear and worry about discrimination and rejection from society. Perceive stigma can cause emotional stress, anxiety, depression, suicide attempts, isolation, problems with family relationships, and friendship [7].

This research shows there is a relationship between perceived stigma and treatment delay. If there is no stigma, it will lead to a good seeking treatment so that it does not cause delays in seeking treatment for leprosy. The study also found that leprosy patients who received stigma showed a delay in seeking treatment. Many respondents keep their illness a secret to their neighbors and family, they felt better if not many people know about the disease because they feel ashamed of their condition. Feeling of shame that ultimately makes respondents not want to go out and seek treatment. This has finally led to a delay in seeking leprosy treatment. Stigma is one of the factors that cause delays in patients getting treatment, this is because the patient's fear will be known by others that they were infected with leprosy and are unwilling to seek medical treatment quickly. This situation does not support the process of treatment and healing, on the contrary, it will increase the risk of disability for the patient himself [8, 9]. The results of this study are not in line with research conducted in Nepal, the study showed no relationship between stigma and treatment delay. Although the findings of quantitative information do not indicate a significant relationship between stigma and patient delay, information from in-depth interviews reveals that a significant level of stigma is inherent in leprosy. This is the reason for lepers to keep their illness a secret and thus leads to a late search [10].

\section{Conclusion}

Respondent characteristics (age, gender, education level, income level), level of knowledge, attitudes toward perceived symptoms, perceived vulnerability and seriousness of symptoms, family support, and access to health services are no risk factors for delay in seeking treatment. However, Perceived Stigma was a risk factor for delays in seeking treatment for leprosy patients ( $\mathrm{p}=0.002$ and OR $4.458(95 \% \mathrm{CI} ; 1,700-11,690)$ 


\section{References}

1. Walker SL, Withington SG, Lockwood DNJ. Leprosy. In: Farar J, Junghans T, LalloD, Hotez PJ, Kang G, White NJ (ed). Manson's Tropical Infectious Diseases (Twenty-third Edition), Elsevier BV, (2020):506-518

2. Van Brakel WH, Post E, Saunderson P, Gopal PK. Leprosy. International Encyclopedia of Public Health (Second Edition) (2017);391-401

3. Ministry of Health, the Republic of Indonesia. Profil kesehatan Indonesia 2017. Jakarta: Kemenkes, (2018). P1-184

4. Ministry of Health, the Republic of Indonesia. Infodatin kusta tahun 2018. Jakarta: Pusat Data dan Informasi Kemenkes RI; (2018)

5. Noordeen SK. Leprosy control through multi drugs therapy (MDT). Bull. World. Heal. Org (1991);69(3):263-269

6. Regency Health Office of Tuban. Laporan kasus kusta Kabupaten Tuban. Tuban: DKK, (2018)

7. Van Brakel WH, Sihombing B, Djarir H, Beise K, Kusumawardhani L, Yulihane R, et al. Disability in people affected by leprosy: the role of impairment, activity, social participation, stigma and discrimination. Glob Heal Action. (2012);1(5):1-11.

8. Sundar Rao PS. Perspectives on the impact of stigma in leprosy: strategies to improve access to health care. Research and Reports in Tropical Medicine 2015;2015(6):49-57

9. Van Brakel WH, Peters R, da Silva Pereira ZB. Stigma related to leprosy - A scientific view. In: Scollard DM, Gillis TP (ed), International textbook of leprosy. URL: www.internationaltextbookofleprosy.org.

10. Choulagai B, Onta S, Bhattarai P. Patient delay in leprosy treatment in Jhapa District Nepal. J Nepal Health Res Counc. (2005);3(2):29-34. 